\title{
Immunohistochemical Localization of Lipoperoxidation Products in Normal Human Placenta
}

\author{
A. Casasco ${ }^{a, c}$, A. Calligaro ${ }^{a}$, M. Casasco ${ }^{a}$, S. Tateo ${ }^{b}$, A. Icaro Cornaglia ${ }^{a}$, M. Reguzzoni ${ }^{a}$ and \\ A. Farina \\ a Institute of Histology and Embryology, University of Pavia, via Forlanini 10, 1-27100 Pavia, Italy \\ ${ }^{b}$ Obstetrics and Gynecology Clinic, I.R.C.C.S. 'San Matteo' Hospital, 1-27100 Pavia, Italy \\ Paper accepted 31 October 1996
}

+-Hydroxynonenal (t-HNE) is a major propagation product of lipid peroxidation that is supposed to be responsible for some of the effects associated with oxidative stress in tissues. We have investigated the possible occurrence and distribution of t-HNE-immunoreactivity in human normal placenta using immunocytochemistry. Specific immunostaining was observed in cytotrophoblast cells, syncytiotrophoblast, some cells of the villous mesenchyme and some endothelial cells of first trimester and term placentae. The detection of $4-H N E$-immunoreactivity in placenta raises the question whether lipoperoxidation products are produced locally in placental cells or represent exogenous products that derive from maternal blood flow. Since trophoblastic cells and villous macrophages are provided by a scavenger receptor, it is conceivable that these cells may play a protective role with regard to the diffusion of lipoperoxidation products from the mother to the embryo. However, since a significant degree of lipid oxidative modification does not take place in plasma, it is presumed that $+\mathrm{HNE}$ is a local product of placental metabolism. In line with this hypothesis, it is proposed that maternal low density lipoproteins, which are the major source of cholesterol for placental steroid synthesis, might be oxidized by villous cells during their traversal through the villous wall.

Placenta (1997), 18, 249-253

(C) 1997 W. B. Saunders Company Ltd

\section{INTRODUCTION}

Human placental cells interact with all of the major classes of normal circulating lipoproteins, and lipoprotein metabolism is related to fetal growth and development (Kinopp et al., 1985, 1991). Recently, scavenger receptor activity has been demonstrated in placental cells in vitro, thus suggesting that placenta may bind and metabolize also modified lipoproteins (Malassiné ct al., 1990; Bonet et al., 1995). There is also cridence that lipoprotein oxidation may be enhanced in pregnancy (Ishihara, 1978; Hubel et al., 1989) and it has been presumed reasonably that normal lipoproteins might be oxidized by trophoblast cells (Bonct et al., 1995).

Polyunsaturated fatty acids (PUFA), major components of all circulating lipoproteins, are amongst the most susceptible molecules to oxidative stimuli within the cell. During the oxidative degradation of PUFA, a varicty of reactive aldehydic products-including t-hydroxynonenal (t-HNE) and malondialdehyde-are formed. Thesc products are capable of attaching covalently to protein, particularly to the epsilon amino groups of lysine residues, thus producing important biological actions (for a review sec Estebaucr, Schaur and Zollner, 1991). Because of its stability, 4-HNE, as a major propagation product of lipid peroxidation, represents a suitable

\footnotetext{
"To whom correspondence should be addressed.
}

$01+3-f(00+/ 97 /(0+02+9+05512.00 / 0$ epitope to reveal the sites of lipid peroxidation using immunochemical methods (Yla-Herttuala et al., 1989; Palinski et al., 1990; Rosenfeld et al., 1990).

The aim of our study was to investigate the possible occurrence and distribution of +HNE-immunoreactivity in human normal placenta using immunohistochemistry.

\section{MATERIALS AND METHODS}

\section{Sample collection and preparation}

First trimester human placentae $(n=13)$ were collected from legal abortions at $8-12$ weeks of pregnancy. Reasons for interruptions were unlikely to affect placental function and structurc. Full-term placentac $(n=2.3)$ were obtained from vaginal delivery after uncomplicated pregnancy.

Placental tissue was cut into blocks that were immediately immersed in a solution of + per cent paraformaldehyde $(w / v)$ in $0.1 \mathrm{M}$ phosphate buffer, $\mathrm{pH} 7.4$ for $6-8 \mathrm{~h}$. To examine whether 4 -HNE-reactive material was produced during tissue fixation and embedding, either $0.9 \mathrm{mmol} / \mathrm{l}$ azide, a myeloperoxidase inhibitor, or $20 \mu \mathrm{mol} / 1$ butylated hydroxytoluene and $2 \mathrm{nmol} / 1$ EDT 4 were added to the fixative used for some placentae (Boyd et al., 1989; Palinski et al., 1989, 1995; Hazell et al., 1996). After washing in phosphate buffer, the specimens

' 1997 11. B. Saunders Company Ided 
were dehydrated through graded concentrations of ethanol, embedded in paraffin, and sectioned at $5-10 \mu \mathrm{m}$.

\section{Immunohistochemistry}

Staining protocol. Dewaxed sections were processed for the immunohistochemical demonstration of $4-\mathrm{HNE}$ according to the indirect biotin-streptavidin immunoperoxidase technique (Hsu, Raine and Fanger, 1981). Briefly, the sections were incubated serially with the following solutions: (1) 0.3 per cent hydrogen peroxide for $30 \mathrm{~min}$ to remove endogenous peroxidase activity; (2) normal goat serum, diluted $1: 20$, for $30 \mathrm{~min}$ to reduce non-specific background staining; (3) mouse monoclonal antibodies to $4-\mathrm{HNE}$, at a range of dilutions (a dilution of $1: 200$ with overnight incubation at $4^{\circ} \mathrm{C}$ was found to be optimal); (t) pre-diluted biotinylated goat anti-mouse IgG (Super Sensitive kit BioGenex, San Ramon, USA), for $1 \mathrm{~h}$ at room temperature; (5) pre-diluted streptavidin-biotinylated peroxidase complexes (Super Sensitive kit, BioGenex, San Ramon, USA), for $1 \mathrm{~h}$ at room temperature; (6) 0.03 per cent, 3,3'diaminobenzidine tetrahydrochloride, to which hydrogen peroxide $(0.02$ per cent) was added just before use, for $5 \mathrm{~min}$ at room tempcrature. Each solution was prepared in $0.05 \mathrm{M}$ Tris buffer, $\mathrm{pH} 7.4$, containing $0.1 \mathrm{~mol} / \mathrm{l} \mathrm{NaCl}(0.15 \mathrm{M}$ Trisbuffered saline) and between each step of the immunostaining procedure the sections were washed in the same buffer. Some sections were lightly counterstained with haematoxylin. The sections were finally dehydrated, mounted and observed in a Zeiss microscope equipped with Nomarski differential interference contrast device.

t-HNE-antibodies and specificity combrols of the immunohistochemical raction. Mouse monoclonal antibodies against t-HNE (clones $1 \mathrm{~g}+\mathrm{h} \bar{\gamma}$ and $1 \mathrm{~h}+\mathrm{h} 12$, subtypes $\operatorname{IgG} 1 \mathrm{k}$ ) were produced using t-hydroxynonenal coupled to bovine serum albumin. The epitope recognized by these clones was found to be t-hydroxynonenal bound to hystidine. This epitope is recognized on any +-HNE-modificd protein so far tested, while native proteins do not show cross-reactivity. With regard to clone $\lg +\mathrm{h} 7$, less than 1 per cent cross-reactivity exists to 4-HNE-lysine or H-HNE-cysteine. With regard to clone $1 \mathrm{~h}$ hh 12, t-HNE-lysine is recognized with about 20 per cent cross-reactivity, while + -HNE-cysteine shows 2 per cent crossreactivity (data not shown). We have performed specificity tests, including adsorption of the antibodies with related and unrelated antigens, omission of the first layer and substitution of an inappropriate antiserum or a non-immune serum for the specific primary antibodies (Polak and Van Noorden, 1986). Immunostaining was completely prevented by absorption of HNE-antibodies with $\mathrm{HNE}$ coupled to albumin, whereas native albumin was uneffective in absorbing the antibodies (10 $\mathrm{nmol}$ in $1 \mathrm{ml}$ antibodies diluted $1: 200$ in tris buffer).

As a further control of $4-H N E$-immunostaining, we have used human carotid atherosclerotic lesions, which are known to contain 4-HNE-modified lipoproteins (Yla-Herttuala et al., 1989; Palinski et al., 1990; Rosenfeld et al., 1990), as positive control tissue.

\section{RESULTS}

Specific +HNE-immunoreactivity was observed in all placentae examined. The reaction appeared finely granular within the cytoplasm of trophoblast cells. In first trimester placentae, cytotrophoblast cells displayed stronger immunoreactivity compared with syncytiotrophoblast [Figure 1(A)]. In term placentae, where cytotrophoblast cells are greatly decreased in number, positive staining was observed in the syncytium [Figure 1(B)]. In the villous stroma of both first trimester and term placentae, mesenchymal cells and blood vessel endothelium were occasionally stained (Figure 2). No specific staining could be observed in control sections. Inclusion of antioxidants during tissue fixation did not result in any apparent differences in the staining (data not shown) when compared with tissues fixed using the routine procedure, indicating that the material recognized by + -HNE-antibodies was not generated during sample preparation.

As a positive control of $4-\mathrm{HNE}$-immunocytochemical reaction, we revealed also $4-H N E$-like immunoreactive material in atherosclerotic plaques (data not shown). The immunoreactivity pattern and the tissue distribution observed in our samples matched well with those reported in previous immunohistochemical studies (Yla-Herttuala et al., 1989; Palinski et al., 1990; Rosenfeld et al., 1990).

\section{DISCUSSION}

This study shows the occurrence and distribution of $4-\mathrm{HNE}$, a major propagation aldehydic product of lipid peroxidation, in normal human placenta. To date, the tissue distribution of 4-HNE and related molecules have been investigated only in pathological tissues, namely atherosclerotic lesions (Haberland, Fong and Cheng, 1988; Boyd et al., 1989; Yla-Herttuala et al., 1989; Palinski et al., 1990, 1995; Rosenfeld et al., 1990, 1991; Jurgens et al., 1993; Hazell et al., 1996). These investigations have provided convincing evidence that lipoperoxidation products actually occur in atherosclerotic plaques, thus providing further support to the hypothesis that oxidized lipoproteins might be involved in the pathogenesis of atherosclerosis (for a review see Witzum and Steinberg, 1991).

In general, increasing evidence exists that aldehydes generated during the process of lipid peroxidation are responsible for some of the effects associated with oxidative stress in cells and tissues (for a review see Esterbauer, Schaur and Zollner, 1991). In fact, unlike reactive free radicals, aldehydes are rather long lived and can attack intracellular targets that are distant from the initial free radical event. Therefore, it has been proposed that t-hydroxyalkenals, such as 4-HNE, may be 


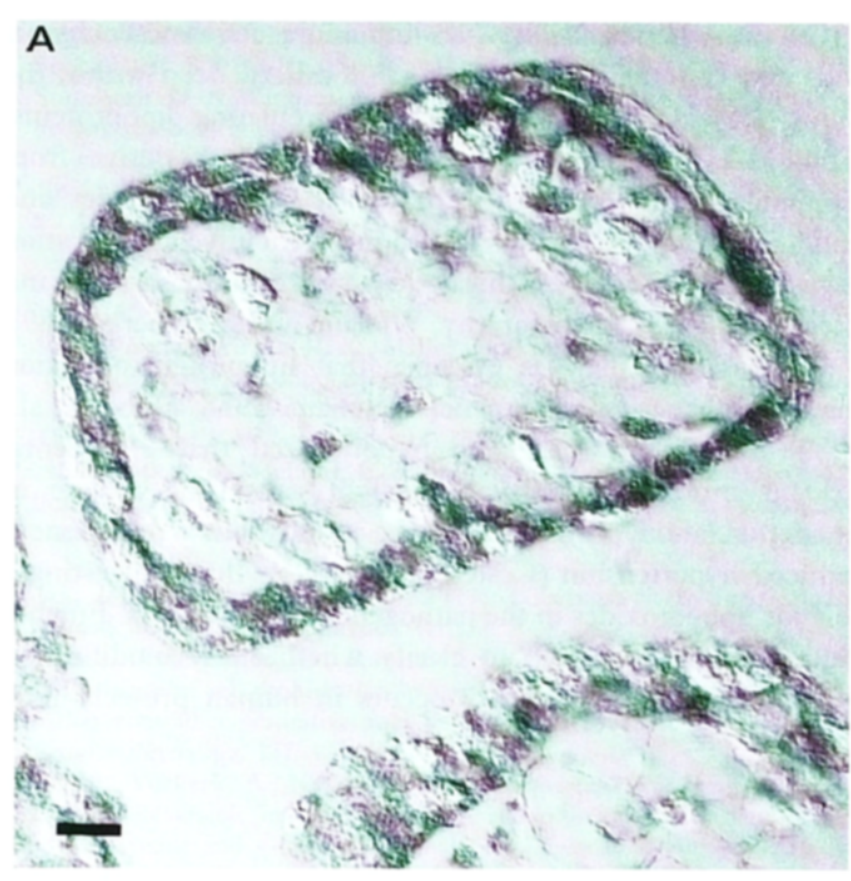

B

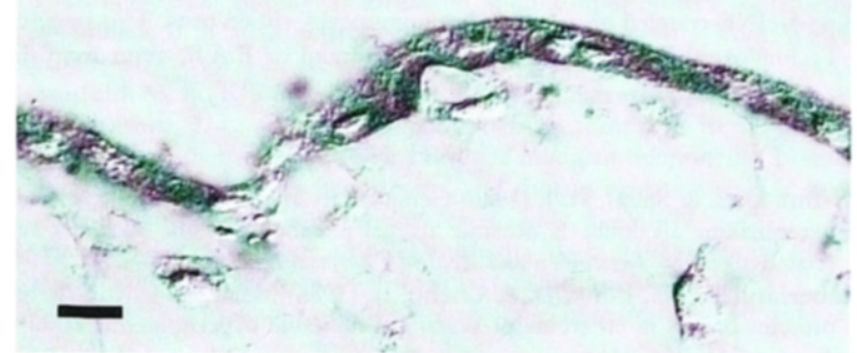

Figure 1. Immunohistochemical localization of t-hydroxynonenalimmunoreactivity in (A) human first trimester and (B) term placentac. Immunostaining is detectable in trophoblast layers and some mesconchymal cells of he villous stroma. In first trimester placenta, the reaction is more intense in cytotrophoblast cells than in forming syncytiun (A). In $1 \mathrm{rm}$ placentat, where cytotrophoblast cells are reduced in number, the staining is visible in the syncytium (B). Indirect immunoperoxidase method. Bar $=0.01 \mathrm{mn}$

considered as second toxic messengers of the chain reactions that are initiated if polyunsaturated fatty acids are converted in lipid hydroperoxides (Esterbauer, Schaur and Zollner, 1991). In this connection, it must be considered that hydroxyalkenals are highly reactive molecules, that are able to react with $\mathrm{SH}$ and $\mathrm{NH}$ groups contained in aminoacids, proteins and nuclear nucleotides. Indeed, an extensive literature exists concerning the possible biological effects of hydroxyalkenals in cells and tissues. These include: (1) cytotoxicity (due to inhibition of DNA, RNA and protein synthesis, disturbance of calcium homeostasis, inhibition of respiration and glycolysis; Hauptlorenz et al., 1985; Griffin and Segal, 1986; Poot et al., 1988b); (2) modulation of adenylate cyclase activity and stimulation of phospholipase C (Dianzani, 1982; Rossi, Garramone and Dianzani, 1988; Rossi et al., 1990); (3) induction or reduction of gene transcription (such as c-myc; Barrera et al., 1987; Cajone, Salina and Benelli-Zazzera, 1989); and (4) cell

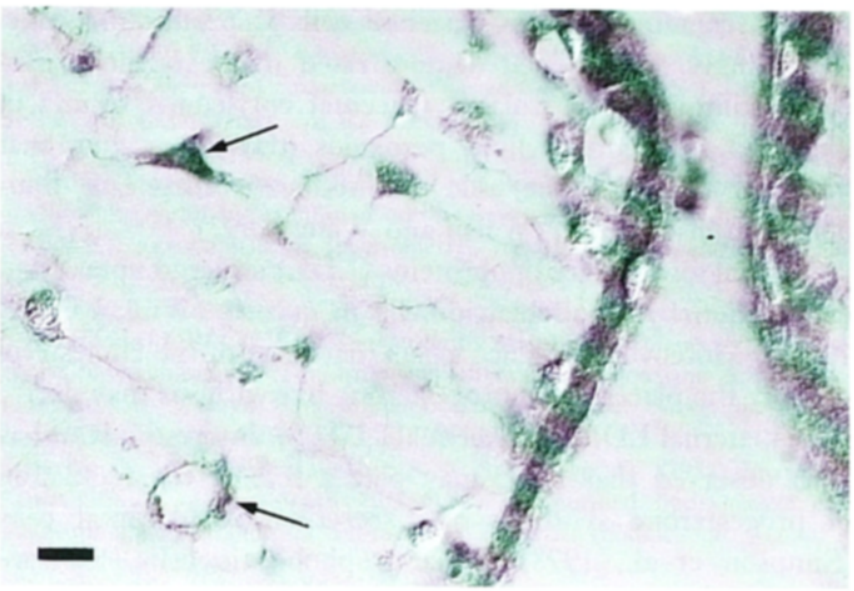

Figure 2. Immunohistochemical localization of t-hydroxynonenalimmunoreactivity in human normal placenti. Beside trophoblast cells, some mesenchymal cells and endothelial cells of the villous stroma (Arrows) display positive staining. indirect immunoperoxidase method. Bar $=0.01 \mathrm{~mm}$.

growth inhibition (through inhibition of DNA polymerase system; Brambilla et al., 1986; Wawra et al., 1986; Poot et al., 1988a,b).

Although the formation of reactive aldehydes has been mostly studied in pathological or experimental systems, it has been shown that t-HNE may also be produced physiologically, c.g. as a product from the peroxidation of liver microsomal lipids (Benedetti et al., 1979; Benedetti, Comporti and Esterbauer, 1980). This raises the possibility that physiological levels of hydroxyalkenals may have a role in normal cell metabolism.

To date, there is no information in the literature about the possible activity of $+\mathrm{HNE}$ and other hydroxyalkenals in placenta. The detection of t-HNE-immunoreactivity in placenta raises the question whether lipoperoxidation products are produced locally in placental cells or represent exogenous products that derive from maternal blood flow. Scavenger receptor activity has been demonstrated in placental trophoblast cells and macrophages in vitro, thus suggesting that placenta may bind also oxidated lipoproteins that circulate in maternal blood flow (Malassiné et al., 1990; Bonet et al., 1995). In the case lipoperoxidation products including +HNE actually derive from maternal circulation, it may be speculated that trophoblast cells and mesenchymal cells displaying +-HNEimmunoreactivity may play a protective role with regard to the diffusion of lipoperoxidation products from the mother toward the embryo.

However, very low levels of $4-\mathrm{HNE}$ are detectable in plasma under physiological condition (Selley et al., 1989) and it has been reasoned that significant degree of lipid oxidative modification does not take place in plasma because of its high antioxidant content (Witzum and Steinberg, 1991). Thus, according to current hypothesis about oxidated lipoprotein formation (Witzum and Steinberg, 1991), it is presumable that lipid oxidative modifications occur mainly in tissuc or cell microdomains that are sequestered from the many plasma antioxidants. In line with this view, it may be speculated that 
4-HNE contained within placental cells is produced locally. Accordingly, it has been demonstrated that exogenous peroxide stimulation of isolated placental cotyledons results in increased secretion of lipid peroxides, thus suggesting that placental cells may be able to produce and release lipoperoxides also in vivo (Walsh and Wang, 1993).

Normal low density lipoproteins (LDL) undergo uptake and degradation by trophoblastic cells in culture (Winkel et al., 1980a). Moreover, evidence exists that most of the cholesterol used by the placenta for progesterone biosynthesis may derive from maternal LDL (Winkel et al., 1980b). Interestingly, it has been observed that LDL may play a role in the regulation of progesterone synthesis and secretion by placental cells (Simpson et al., 1978). Since trophoblastic cells, that we have found to be + -HNE-immunoreactive, are provided by scarenger receptor, it may be hypothesized that I.DI. might be oxidized by trophoblast cells during blood traversal through the intervillous space.
On the other hand, 4-HNE-immunoreactive mesenchymal cells and endothelial cells, that are localized deep within the villus, should lack direct access to circulating lipoproteins. Thus, 4-HNE contained in villous cells may derive from trophoblast cells or may be produced by macrophages and endothclium that are able to produce oxidative modification via the lipoxygenase pathway (Sparrow, Parthasarathy and Steinberg, 1988; Parthasarathy, Wieland and Steinberg, 1989).

Interestingly, there is eridence that lipoprotein oxidation may be enhanced in pregnancy (Ishihara, 1978; Hubel et al., 1989). Recently it has been hypothesized that a placental oxidant-antioxidant imbalance might cause the release of lipoperoxidation products into the circulation in pregnancyinduced hypertension (Cester et al., 1994), thus suggesting a role for lipoperoxides in the pathogenesis of eclampsia. Further study will be addressed to clarify whether any modification of t-HNE-immunorcactivity occurs in human pre-celamptic placenta.

\section{ACKNOWLEDGEMENTS}

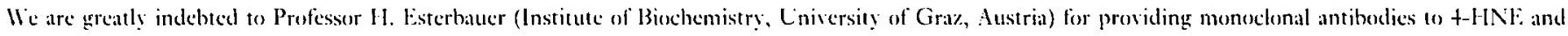
to Professor (3. Bellomo (Institute of Pathology, Lniversity of l'lurin, laaly) for providing t-HNE-coupled proteins used in inmunoabsorption tests. This rescarch was supported by grants from the Italian Ministry of Universily and Scientific and Technological Rescarch (t) per cent funds) and by E.A.R. grant from the Unirersity of Pavia, Italy.

\section{REFERENCES}

Barrera, G., Martinottie, S., Fazio, V., Manzari, V., Paradisi, I.., Parolam, M., Frati, I. \& Dianzani, M. U. (1987) Inhibition of the

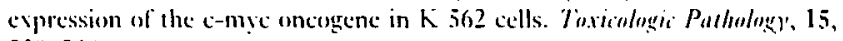
$238-2+11$.

Benedetti, A., Comporti, M. \& Esterbauer, H. (1980) Identification of t-hodroxenonenal as a crotoxic originating fiom the peroxidation of liver

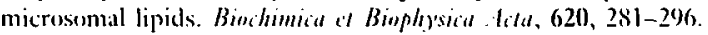

Benedetti, 1., Casini, A. F., Ferrali, M. \& Comporti, M. (1979) Fixtraction and partial characterization of dialysis products originating forom the peroxidation of liser microsomal lipids and inhibiting slacosc 6-phosphatase activity. Binchemical Pharmacolog), 28, 20(0)-2915.

Bonct, B., Chatit, A., Gowan, A. M. \& Knopp, R. H. (1985) . M(taloblism of moditied [.I)I, hy cultured human placental cells. thoresileresis, 112, $125-136$.

Boyd, H. C.., Gowan, A. M., Wolfbauer, G. \& (hatit, A. (1984) I)irect evidence for a protein recognized by a monoclonal antibods against oxidatively modified I.DI, in atheroscterotic lesions from Watanabe heritable hyperlipemic rabbit. Imerical fourmal of Pat/holog), 135, \$15-826.

Brambila, G., Sciaba, L., Faggin, P., Maura, A., Marinari, L. M., Ferro, M. \& Esterbauer, H. (1986) Cytotoxicity, I)N firagmentation and sister-chromaticl exchange hamster wary cells cxposed to the lipid peroxidation product t-hydroxynonenal and homologous aldehydes. Hutation Resiorch, 171, 169-170.

Cajone, F., Salina, M. \& Benelli-Zazzera, A. (10Sy) +-1 lydroxymomenal induces a 1) VA-bineling protein similar to the heat-shock lacter. Biodermis/r) . 7mmal, 262, 9ד̄-979.

Cester, N., Staffolani, R., Rabini, R. A., Magnanelli, R., Salvolini, l:., Galassi, R., Mazzanti, L. \& Romanini, C. (19(9) Pregnancy induced hypertension. A role for perovidation of microvillous plasma membranes. . Holccular and Cellular Bawh'mistrl, 131, 151-155.

Dianzani, M. U. (19\$2) Biochemical effects of satteated and unsiturated

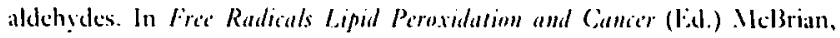
1). (.. II. \& Slater, 'T. F. pp. 129-15s. I.ondon: Acidemic P'ress.

Esterbauer, H., Schaur, R. J. \& Zollner, H. (1901) (hemistry and biochemistry of t-hydroxynonemal, malonaldehyde and related aldehrdes.

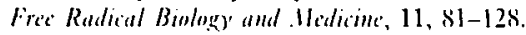

Griffin, D. S. \& Segal, H. J. (1986) Genotoxicity and cytotoxicity of selected pyroolizidine alkaloids. A possible alkenal metabolice of the alkiloids and related alkenals. Toxicolog) and . Applied Pharmacolog), 86, 227-23.

Haberland, M. E., Fong, D. \& Cheng, I. (1988) Malondialdehyde-iltered proteins occurs in atheroma of IIatanabe heritable hyperlipielenic rabbits. Sitinat, 241, 215-241.

Hazell, L. J., Arnold, I., Flowers, D., Waeg, G., Malle, E. \& Stocker, R. (1996) Presence of hypochlorite-medified proteins in human atherosclerotic lesions. Jourmal of Cilinical lmatsigaliom, 97, 15.35-15+4.

Hauptlorenz, S., Fsterbauer, H., Moll, W., Pumpel, R., Schaucnstein, E. \& Puschendorf, B. (1985) E.fiects of the lipid peroxidation product t-hydroxynonenal and related alalehydes on proliferation and viability of

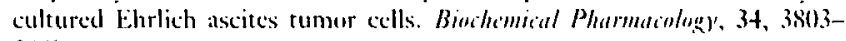
$3 \times 109$.

Hsu, S.-MI, Raine, L. \& Fanger, H. (1981) use of asidin-biotin-peroxidase complex (ABC) in immunoperoxidase techniques: a compariton hetween

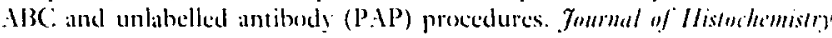

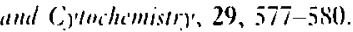

Hubel, C. A., Roberts, J. M., Taylor, R. N., Musci, T. J., Rogers, G. M. * McLaughlin, M. K. (1985) I ipid peroxidation in pregnancy: now

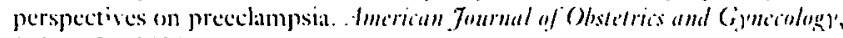
$161,1025-1034$

Ishihara, M. (1978) Studies on lipoperoxide of normal pregnant women and patients with toxemia of pregnancy. Climia Chimiat ta 4 , 84, 1-9.

Jurgens, G., Chen, Q., Esterbauer, H., Mair, S., Ledinski, G. \& Dinges, H. P. (198.3) Immunostaining of human autopsy aortas with antibudies to

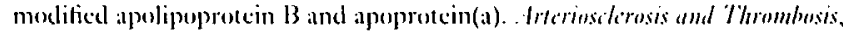
13. $1689-1699$

Knopp, R. H., Bergelin, R. O., Wahl, P. W. \& Walden, C. E. (1985) Regulationships of infant birth size to matcrnal lipoproteins, apoprotcin, fecel, hormones, clinical chemistries and body weight at in wects acstation. Dialictes, 34, $71-77$.

Knopp, R. H., Magec, M. S., Bonet, B. \& Gomea-Coronado, D. (149) l.ipid metabolism in pregnancy In Principles uf Perinatal-.ionatal Il'tabohsm. (F.d.) Cowett, R. M. pp. 17/-203. New lork: Springer-Verlag.

Malassine, A., Alsat, E., Besse, C., Rebourcet, R. \& Cedard, L. (19\%) deetylated low density lipoprotein endocytosis by human syncytiotrophoblast in culture. Placina, 11, 191-204. 
Palinski, W., Rosenfeld, M. E., Yla-Herttuala, S., Gurtner, G. C., Socher, S. S., Butler, S. W., Parthasarathy, S., Carew, T. E., Stcinberg, D. \& Witzum, J. L. (1989) I.ow density lipoprotein undergo oxidative modifications in vivo. Procedings of the National fademy of Sciences of the LS. $1,86,1372-1376$.

Palinski, W., Yla-Herttuala, S., Rosenfeld, M. E., Butler, S. W., Socher, S. A., Parthasarathy, S., Curtiss, L. K. \& Witztum, J. L. (1990) Antisera and monoclonal antibodies specific for epitopes generated during oxidative modification of low density lipoprotein. Irteriositerosis, 10 , $325-335$.

Palinski, W., Tangirala, R. K., Miller, E., Young, S. G. \& Wit\%um, J. L. (1995) Increased autoantibody titers against epitopes of oxidized I.DI, in I.I)], receptor-deficient mice with increased atherosclerosis. . Irteriosileroris, Thrombosis and liscular Biology, 15, 1569-1576.

Parthasarathy, S., Wicland, E. \& Steinberg, D. (1989) Enzymatic modification of low density lipoprotein by purified lipoxygenase in the oxidative modification of low density lipoprotein. Procedings of the National fialsm) of Scicues of the (iSt, 86, 1946-1050.

Polak, J. M. \& Van Noorden, S. (1986). Immunocylodh'mistry'. Holern Wetheds and Ipplicarions. Bristol: Wright.

Poot, M., Esterbauer, H., Rabinovitch, P. S. \& Hochn, H. (1988a) Disturbance of cell proliferation by two model compounds of lipid peroxidation contradicts causative role in probiferative senescence. Fonmal of Céllular Physiolog), 137, +21-429.

Poot, M., Verkerk, A., Koster, J. F., Esterbauer, H. \& Jongkind, J. F. (1988b). Reversible inhibition of DNA and protcin synthesis by eumene

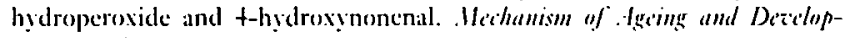
mint, $+3,1-9$.

Rosenfeld, M. E., Palinski, W., Yla-Herttuala, S., Butler, S. \& Witztum, J. I. (199(0) Distribution of oxidation specitic lipid-protein acklucts and apoprotein $B$ in atherosclerotic lesions of varying screrity from WHHI. rabbits. Areriosilerosis, 10, 336-349.

Rosenfeld, M. E., Khoo, J. C., Miller, E., Parthasarathy, S., Palinski, W. \& Witztum, J. J. (1991) Materophage-derived form cells freshly isolated from rabbit atheresclerotic lesions degrade modified lipoproteins, promote oxidalion of low-density lipoproteins, and contain oxidation-specific lipidprotein adelucts. Jommal of Climical /messigation, 87, 90-99.

Rossi, M. A., Garramone, A. \& Dianzani, M. U. (19S8) Stimulation of phospholipase (: activity by t-hydodoxynonenal: influence of G'TP' and

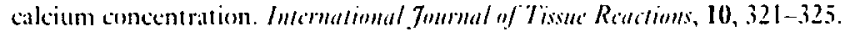

Rossi, M. A., Fidale, F., Garramone, A., Esterbauer, H. \& Dianzani, M. U. (1990) Effect of t-hydroxyalkenals on hepatic phosphatidylinositol4,5-biphospholipase C. Biochemical Pharmacology', 39, 1715-1719.

Selley, M. L., Bartlett, M. R., McGuiness, J. A., Hapel, A. J., Ardlie, N. G. \& Lacey, M. J. (1989) Determination of the lipid peroxidation product tans-t-nonenal in biological samples by high performance liquid chromatography and combined capillary gas chromatography/negative ion chemical ionization mass spectronetry. Jourmal of Chromatography', 488, $329-3+0$.

Simpson, E. R., Porter, J. C., Milewich, L., Biheimer, D. W. \& MacDonald, P. C. (1978) Regulation by plasma lipoproteins of progesterone biosinthesis and 3 -hydroxy-3-methylglutaryl coenzyme it reductase activity in cultured human choriocarcinoma cells. Journal of Climical Endocrinolog' and Malabolism, 47, 1099-1105.

Sparrow, C. P., Parthasarathy, S. \& Steinberg, D. (1988) Enzymatic modification of low density lipoprotein by purified lipoxygenase plus phospholipase A2 mimics cell-mediated oxidative modification. Jourmal of Lipid Resi'urch, 29, 745-753.

Walsh, S. W. \& Wang, Y. (1993) Secretion of lipid peroxides by the human

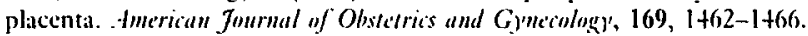

Wawra, E., Zollner, H., Schaur, R. J., Tillian, H. M. \& Schauenstein, E. (1986) The inhibitory effece of t-hydroxynonenal on DNA-polymerases alpha and beta from rat liver and rapidly dividing Yoshida ascites hepatoma C'll Biochimistru' and Function, 4, 31-36.

Winkel, C. A., Gilmore, J., MacDonald, P. C. \& Simpson, E. R. (1980a) Uptake and degradation of lipoproteins by human trophoblastic cells in primary culture. Endocrinolog)', 107, 1892-1898.

Winkel, C. A., Snyder, J. M., MacDonald, P. C. \& Simpson, E. R. (1980b) Regulation of cholesterol and progesterone synthesis in humin placental cells in culture by serum lipoproteins. Fmlocimolow', 106, $10.5+-1060$.

Witztum, J. I. \& Steinberg, D. ([99]) Role of oxidized low density lipoprotein in atherogenesis. fommal of Climial Imesigalion, 188, 17651792 .

Yla-Herttuala, S., Palinski, W., Rosenfeld, M. E., Parthasarathy, S., Carew, T. E., Butler, S., Witztum, J. I. \& Stcinberg, D. (1989) Evidence for the presence of oxidatively moditied low densily lipoprotein in atherosclerotic lesions of rabbit and mian. Fournal of Climical Inestigation, $84,108(10-10 \%)$ 